Vadym Zheltovskyy

Uniwersytet Warszawski

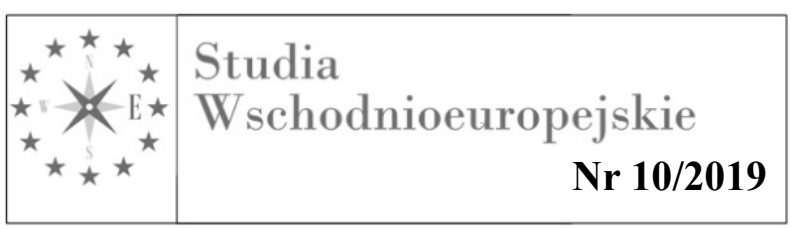

\title{
Decentralization Issue in Ukrainian Political Discourse: Selected Cases
}

$\mathrm{T}$ he reforms of local self-governance and decentralization has been widely discussed in Ukrainian political circles since 2014 Euromaidan events and election of Post-Maidan authorities. In fact, newly elected leaders clearly declared their will to reform the sector of local governance in Ukraine as well as to implement the good practices of European countries on the matter. Additionally, the issue of decentralization was presented in all political programs of parties taking part in 2014 parliamentary elections. At the same time, it became a controversial issue which divided political camps in 2015 during the voting on presidential decentralization bill. That controversy de facto stopped the legal procedures on the adoption of legal framework for the self-governance reform in Ukraine.

As far as the controversy mentioned above, the issue of decentralization was regularly used in political debates to win the public support for the position of particular party or political leader. Therefore, the major purpose of the article is to explain the way in which political discourse on decentralization bill was used by different political parties in Post-Maidan Ukraine. To reach the stated purpose the following research tasks are taken into consideration:

- the analysis of major features of presidential decentralization bill submitted by Petro Poroshenko

- political circumstances under which the political debates on decentralization bill took place

- political outcomes of delivered rhetorical messages and their impact on decentralization in Ukraine.

\section{The Essence of Political Discourse and Its Place in Contemporary Politics}

As a matter of fact, it was Aristotle who asserted that humans are "political beings who alone of the animals [are] furnished with the faculty of language" 116 who use their rhetorical messages to convince the listener 117 . Whereas the contemporary scholars specializing in political communication share the viewpoint of Aristotle, they adjust their research to existing political and cultural peculiarities. To present a comprehensive scientific perspective of the matter,

the following shall be taken into consideration. In context of political processes, Denton asserts that because communication is the fundamental process of human interaction, institutions, legitimacy, statutes, leaders, sanctions, interests, ideologies, and coalitions are socially 
constructed through language118. Clearly, neither politics nor government can exist without communication. This statement is shared by Chilton who points out that politics is about using the language 119 .

In her turn, Bogusława Dobek - Ostrowska defines the notion of political communication as a two - way process, which occurs in a particular social, political, media and cultural settings. Despite the fact that politics and communication are two independent areas of human activity there exists a close connection between them120. Furthermore, Fairclough and Duszak put emphasis on the discourse ability to leverage opinion of politicians and the public with the help of advertisement campaigns, lobbing, etc.121.

As far as the research on political communication in the United States of America is concerned, it gives crucial insights into the connection between politics and communication that are of particular importance for article research. In his book Political Communication: Politics, Press and Public in America, Perloff points out the connection between communication and self-government. Scholar states that communication has always played a role in politics in the United States, which has been a part of the dynamic experiment in selfgovernment that America's Founding Fathers launched 200 years ago. According to the scholar, that connection between communication and politics was caused by the democratic ideal - the notion that people can govern themselves, elect leaders, and a society by rules of a representative democracy - which has captured the imagination of leaders and citizens in America from the beginning of the nation's history to the present day.

At the same time, author recognizes that since politics is fundamentally about the pursuit and use of power, political communication necessarily involves power considerations. Although leaders have more power than citizens and media, in that they control society's resources, they are not always able to shape the agenda - or the issues under public discussion - in the way they would like. This, in Perloff's opinion, makes political communication dynamic and volatile, which in turn leads to the fact that American system of politics and political communication is a system of fraught with puzzles and paradoxes, and that the manner and style in which politics is communicated in America is a controversial subject122. Interestingly, Perloff's description of political communication in the United States may be more than topical in regard to political communication in Ukraine regarding the reform of selfgovernance that was announced to be one of major priorities of every single political party running for places in Verkhovna Rada in October 2014 Early parliamentary elections.

In terms of other evidences in favour of the connection between politics and communication (presidential in particular) Richard Perloff underlines that politics, broadly defined, concerns the process by which society reaches consensus on policy issues. That is why political communication occurs when citizens, media, and leaders "dialogue" about issues of broad concern to elites or the public. Speaking about the present time, scientist agrees that for

118 R. Denton, Introduction to Craig Allen Smith, Kathy B. Smith, The White House Speaks: Presidential Leadership as Persuasion. New York, 1994, p. 3.

119 P. Chilton, Analysing Political Discourse: Theory and Practice, London: Routledge, 2004, p. 16. Read also: J. Joseph, Language and Politics, Edinburgh, 2006, p. 111.

120 B. Dobek - Ostrowska, Komunikowanie polityczne i publiczne, Warszawa, 2011, s. 129.

121 Fairclough N., Duszak A., Wstęp: Krytyczna analiza dyskursu-nowy obszar badawczy dla lingwistyki i nauk społecznych. „Krytyczna analiza dyskursu. Interdyscyplinarne podejście do komunikacji społecznej”, Fairclough Norman, Duszak Anna (eds.), Kraków, 2008, s. 17. 122 R. Perloff, Political Communication: Politics, Press and Public in America. New York, 1998 p. 6. 
the time being politics gets a bad reputation in the United Sates. However, he is sure about the fact that political communication "can, or should, play a vital role in a democracy" 123 . The Perloff's statement is used in given article in context of the analysis of "dialogue" between Ukrainian citizens and politicians on the matter of self-governance, willingness of both sides to discuss the topic and outcomes of on-going debate.

In fact, Perloff's statement is supported by editors of the book Political Communication in a New Era: a Cross - National Perspective Wolfsfeld Gadi and Maarek Phillipe. In their introduction, scholars continue Perloff's idea by emphasising that communication is and always has been a central component in political processes "whether it is leaders communicating with the public, candidates competing for votes, combatants struggling for international attention and sympathy, or citizens debating public issues" 124.

Finally, according to Craig Allen Smith and Kathy B. Smith, communication serves few important functions in the American system of government, which might be implemented in reference to other governments as well. The functions are following:

to unify a society by fostering sense of inclusion and efficacy among its varied people, interests, values and traditions;

to legitimize by justifying the distribution of power in society. Power holders and aspirants to political power alike ground their claims in a socially accepted doctrine of legitimation that is created, learned, and applied through communication.

to orient a society by defining objectives and problems in coherent narratives that integrate people, interests, values, traditions, power distributions, and spheres of influence. This occurs only through communication, and the characterization of the political landscape frames political reality for the community.

to resolve conflicts by drawing new distinctions, by transcending differences, by verifying actual claims, by weighing arguments, by adjudicating arguments, and by choosing between prospective futures 125 .

\section{The Presidential Bill on Decentralization - Major Features}

The Bill number 2217 "On Amendments to the Constitution of Ukraine (concerning the decentralization of power) 126 " led to political debate inside Ukrainian parliament and dramatic events outside. Therefore, the short characteristics of the document are presented below to explain the most controversial constituents.

The bill was adopted by constitutional commission on 26 June 2015. The proposal on decentralization changes was a topic of discussion between Ukrainian top officials and

\footnotetext{
123 Ibidem, p. 11.

124 G. Woldsfeld, P. Maarek, Political Communication in a New Era: a Cross - National Perspective. New York, 2003, p. 1.

125 C. Smith, K. Smith, The White House Speaks: Presidential leadership as Persuasion. New York, 1994, p. 18. More on this topic read: D. McQuail, Political Communication, „Encyclopedia of Government and Politics”, London, 2001, p. 471-473.

126 za: http://w1.c1.rada.gov.ua/pls/zweb2/webproc4_1?pf3511=55812 (16.07.2015).
} 
leaders of Normandy 4 Format127. Furthermore, the proposal received positive opinion from international leaders and institutions. It was characterized by the head of European Venice Commission as probably the only real approach under existed conditions 128 . In their turn, the German and French leaders noted that the introduction of decentralization amendments and further constitutional reform would guarantee the consolidation of democracy in Ukraine and implementation of the Minsk agreements129. Having said that, it should be stated that such interest from European and American allies (deputy of the U.S. state secretary Victoria Nuland visited Kyiv before the voting on given bill in Verkhovna Rada and was present together with the U.S. Ambassador to Ukraine in parliament during the voting) poses a question on the level of international engagement into the given matter.

Concerning the essence of the 9-page decentralization proposal, the following aspects should be underlined:

- as before, Ukraine will be consisted of 27 regions, including Crimea peninsula and city of Sevastopol;

- administrative territorial system of Ukraine will include hromady, districts (rayons) and regions;

- reduction of amount of districts (rayons): from 490 to 150;

- district (rayon) will include several territorial communities (hromady) that would unite several villages or towns;

- hromady are the primary, basic, and main unit of the administrative and territorial system of Ukraine. They will receive the right to decide on primary and secondary education, emergency services, municipal police, social protection, landscape of territories, etc.;

- hromady will elect councils that will constitute executive body with an elected head of the council;

- regional council will appoint an executive body that will substitute regional state administrations;

- institute of Prefect as a controlling body appointed by the president after cabinet of ministers' nomination. The main task of prefect will be to oversee the compliance with Constitution in policies of local councils etc.130 According to Poroshenko's speech in Parliament: "Prefects would have nothing to do with the management of budget flows and financial resources of the local government. They would not govern but only perform monitoring functions" 131.

\section{The Voting Process on Decentralization Bill}

The article focuses on two stages of the voting process on the decentralization bill which took place on 16 July 2015 when 288 of lawmakers (62 more than the minimum required) voted to send the decentralization bill to the Constitutional Court of Ukraine for review 132 and the first reading vote on 31 August 2015 when 265 parliamentarians gave their votes for the bill.

Proponents and opponents of the bill gave polar arguments explaining their voting decision. The biggest argument was caused by style of changes to the text of the bill on

\footnotetext{
127 Normandy format is a diplomatic group of senior representatives of the four countries (Germany, Russia, Ukraine and France) to resolve the crisis situation in the East of Ukraine. The Normandy format operates mainly through telephone calls between the Ukrainian, Russian and French presidents, the German chancellor and their respective ministers of foreign affairs.

128Project zmin do Konstytucji zberigaje balans, za: http://www.theinsider.ua/politics/559bb0616c6fe/ (8.07.2015).

$129 \mathrm{za}$ : http://rada.gov.ua/en/news/top news/113641.html (15.07.2015).

$130 \mathrm{za}:$ http://w1.c1.rada.gov.ua/pls/zweb2/webproc4_1?pf3511=55812 (16.07.2015).

$131 \mathrm{za}$. http://www.president.gov.ua/en/news/decentralizaciya-nablizit-nashu-politichnu-sistemu-do-yevrop-35658 (16.07.2015).

132 Ibidem.
} 
decentralization a day before the voting. More specifically, on the eve of 16 July voting the presidential draft of the bill was published with the note "revised".

In fact, the most important difference between the revised draft and the first edition, registered in the Verkhovna Rada on 1 July 2015 was the provision that the peculiarities of local self-government in parts of Donetsk and Lugansk regions are defined by a separate law. If the first edition of this provision was put in the transitional provisions of the bill, the revised version of 15 July proposed to insert this rule in transitional provisions of chapter XV of the Constitution of Ukraine. Some commentators connect given last moment edition with the arrival of Victoria Nuland, U.S. Assistant Secretary of State for European and Eurasian Affairs, who was present in Verkhovna Rada together with U.S. Ambassador to Ukraine Geoffrey Pyatt during the voting process 133 .

That very addition was one of the reasons (if not the most important) that led to division inside democratic coalition over their vision on future of local governance in Ukraine and created situational alliance between official opposition and Poroshenko-Yatseniuk duet. The numbers below illustrate the dynamics of voting results according to factions of Verkhovna Rada.

Table 1. 16 July 2015 and 31 August 2015 Votes on Decentralization Bill

\begin{tabular}{|c|c|c|c|}
\hline Faction & 16 July 2015 Vote & 31 August 2015 & $+/-$ \\
\hline Poroshenko Block & 121 & 115 & -6 \\
\hline Narodnyy Front & 71 & 69 & -2 \\
\hline Opposition Block & 34 & 38 & +4 \\
\hline Samopomich Party & 1 & 5 & +4 \\
\hline Liashko Radical Party & 0 & 0 & $\mathbf{0}$ \\
\hline Batkivshchyna Party & 11 & 0 & -11 \\
\hline Volia Narodu Party & 15 & 14 & -1 \\
\hline Vidrodzennia Group & 19 & 11 & -8 \\
\hline
\end{tabular}

Source: author's own analysis of parliamentary votes on 16 July 2015 and 31 August 2015.

Given numbers clearly illustrate the scale of political debate and negotiations behind the closed doors. Parliamentary votes on 16 July 2015 and 31 August 2015 and political disagreement launched by given process left more questions than answers as regards the future of decentralization law in Ukraine. Even though the bill amending the constitution concerning

133 Poroshenko: ti, hto ne golosuvav za decentralizaciju, namagalysia "torpeduvaty myrnyy plan", za: http://www.newsru.ua/ukraine/17jul2015/torpedirovatplan.html (1.07.2016). 
local government reform passed on its first reading the conditions and situation both inside and outside of Verkhovna Rada during the voting process raised further questions on the future of the proposal and timing for the second reading vote which initially was planned on September 2015 but has not taken place so far.

The deputies voted under condition of chaos and disagreement in Verkhovna Rada when members of Radical Party blocked the speaker's position and speaker Groysman delivered his speech and commands from parliamentary tribune occupied by deputies from Poroshenko Block. Additionally, the vote was accompanied by many deputies shouting "Shame!" and rhythmically beating parliamentary benches 134 . More dramatically, the vote led to clashes between protesters representing nationalist party Svoboda and Liashko Radical party with riot police in front of Ukrainian parliament. As a result of grenade thrown into the riot police by one of the protesters, four soldiers from the National Guard were killed and more than 150 people, mainly members of law enforcement agencies, were injured.

\section{The Comparative Analysis of Political Messages on the Decentralization Bill}

In order to summarize the major arguments of both sides the article presents the analysis of major political messages of political leaders on the matter.

\section{Argument 1. Special status}

\section{Supporters of the Bill}

According to Poroshenko speech in Parliament, Ukraine remains unitary state and the bill proposal only suggests the possibility of a specific order of the local government in the individual administrative-territorial units of Donetsk and Lugansk regions, which is to be determined by a separate law135.

\section{Opponents of the Bill}

Special order of the local government is no different from the special status. In accordance with Head Deputy of Constitutional Commission Viktor Musiyaka, the statement was

a game of words since the situation when all subjects of local government have one status, and some areas different one means a special status of those particular areas 136. Moreover, in his interview for Ukrainian respected newspaper Day, Musiyaka criticized the authorities approach to the Constitutional Commission and its role in preparation of the bill proposal describing working process as very specific. As a matter of fact, the commission received a prepared text and did not have time to express their opinion on it since the document was immediately sent to Venice Commission137.

\section{Argument 2. Legal status for self-proclaimed republic in Doneck and Lugansk Supporters of the Bill}

Proponents of the vote state that the law on special order of local self-government in occupied areas of Doneck and Lugansk regions mentioned in proposed amendments to Ukrainian Constitution will come into force only after the elimination of illegal military formations in those territories. However, the Law on peculiarities of local self-government in

\footnotetext{
134 Zminy Konstytucii: decentralizacija pid vyhuky „,Hanba”, za: http://www.radiosvoboda.org/a/27218913.html (08.07.2016).

135 za: www.president.gov.ua/news/vistup-prezidenta-ukrayini-na-plenarnomu-zasidanni-verhovnoy-35657 (2.07.2016).

136 Peremoga chy zrada-shcho oznachayut novi polozhennya Konstytuciji pro status Donbasu, za: http://ua1.com.ua/publications/peremoga-chi-zrada-shcho-oznachayut-novi-polozhennya-konstituciji-pro-statusdonbasu-5917.html (2.07.216).

137 Podrobyci za lashtunkamy konstytuciynoyi komisii, za: http://day.kyiv.ua/uk/article/podrobyci/za-lashtunkamykonstytuciynoyi-komisiyi (2.07.2016).
} 
particular parts of Doneck and Lugansk regions138 was adopted by Verkhovna Rada on 16 September 2014 and has only three year validity term.

\section{Opponents of the Bill}

In their turn, opponents argued that adding to the Constitution provisions on peculiarities of local government in Donbas is a step toward legalization of the so called "Doneck and Lugansk People's Republics". The fact that transitional provisions of the Constitution have the same effect as other chapters shows that there will be necessary to have 300 votes to change it, which means that the statement on local self-government in Donbas might remain in the Ukrainian Constitution for a long time. Additionally, the criticism covered the Law on peculiarities of local self-government in particular parts of Doneck and Lugansk regions for preserving the "republics".

\section{Argument 3. Minsk agreements Supporters of the Bill}

Making these changes to the Constitution is the implementation of paragraph 11 of the Minsk II Agreement that states the following: "Constitutional reform in Ukraine, with a new constitution to come into effect by the end of 2015, the key element of which is decentralization (taking into account peculiarities of particular districts of Donetsk and Luhansk oblasts, agreed with representatives of these districts), and also approval of permanent legislation on the special status of particular districts of Donetsk and Luhansk oblasts in accordance with the measures spelt out in the attached footnote by the end of 2015"139. Therefore, positive voting means that Ukraine is demonstrating its commitment to compliance with international agreements.

\section{Opponents of the Bill}

Opponents pointed to the fact that other points of Minsk II Agreement were not fully fulfilled by any of the sides and therefore there was no rationale to start fulfilling Minsk agreement from paragraph 11 . Another accent was put on the fact that only paragraph 11 had chronological limit as regards its implementation while other paragraphs did not include such norm 140 .

\section{Argument 4. Peace or further separatism moves \\ Supporters of the Bill}

Change of constitution is a part of peace plan of president Poroshenko.

\section{Opponents of the Bill}

Peculiarities of self-government for one part of Ukrainian territory might launch a chain reaction for other parts.

\section{Argument 5. Role of western allies \\ Supporters of the Bill}

The interest of Western partners in such formulation of Donbas status is explained not by their agreements with Russia, but by their desire to quickly end the conflict, and to demonstrate that they fulfill their part of the commitments together with Ukraine while Russia and the separatists - do not do the same. This position can be the basis for the continuation of sanctions against Moscow and the introduction of new restrictions.

\section{Opponents of the Bill}

Western partners dictate Ukraine how to vote and which constitutional amendments should be adopted. That in turn makes Ukraine not a subject but an object of international

\footnotetext{
138 za: http://zakon5.rada.gov.ua/laws/show/1680-18 (2.07.2016).

139 Kompleks mer po vypolneniuju Minskih soglashenii, za: http://www.osce.org/ru/cio/140221?download=true (2.07.2016).

140 Peremoga chy zrada...,op.cit., za: http://ua1.com.ua/publications/peremoga-chi-zrada-shcho-oznachayut-novipolozhennya-konstituciji-pro-status-donbasu-5917.html (2.07.2016).
} 
relations. Apart from this, other countries cannot impact Ukrainian decisions on internal matters. Other arguments referred to Budapest memorandum and insufficient reaction from countries who signed it to Russian aggression toward Ukraine141.

\section{Conclusions}

To conclude on the political messages on the voting process, they illustrated that the vote launched rhetorical campaign on decentralization in all political camps. It also showed that rhetoric was used to promote the decisions made behind the closed doors and in order to get public support for already taken decisions. Furthermore, rhetorical debates on decentralization bill showed that instead of bringing coalition members together, the document divided former allies that furthermore led to division inside civil society. What is more, the debate was rarely about decentralization and self-governance reform itself. Simultaneously, due to the political circumstances, the major attention was paid to the statement on peculiarities of self-government in particular parts of Doneck and Luhansk regions.

At the same time, it should be emphasised that experts agree on positive moments of the adopted bill. As Olszański asserts, the decentralization bill is well constructed and may serve as a basis for establishment of a real system of local government in Ukraine, giving central authorities the necessary instruments to control the situation in the regions 142. Similar opinion is shared by Carnegie analysts who define as the most significant the following points of the bill:

- the right of local councils to establish executive offices, and thus remove an important barrier to decentralization;

- the granting of equal rights to all local communities;

- a provision for the president, acting through local representatives known as prefects, to dissolve local councils or overrule their decisions143.

As a final comment, it should be repeated that the reform of local governance and decentralization was declared to be a priority issue by Post-Maidan authorities in Ukraine. As a matter of fact, there has been a significant number of legal framework in this regard such as changes referring to the voluntarily amalgamation and the status of starosta of village and settlement adopted in 2017 that gives grounds for more effective management and creates conditions for successful implementation of local initiatives. As for September 2018 almost $20 \%$ of Ukrainian population lived in amalgamated territorial units 144 .

However, political discourse on the analysed matter showed that rhetoric is often used by political actors as a tool for promoting own position and with a view to gaining popular support in the light of the 2019 elections. Therefore, the question of a second reading vote on the decentralization bill and constitutional amendments remains topical.

\footnotetext{
141 Ibidem.

142 T. Olszański, Ukraine is divided over constitutional reform, za: http://www.osw.waw.pl/en/publikacje/analyses/2015-09-02/ukraine-divided-over-constitutional-reform (08.07.2016).

143 Ukraine Reform Monitor 2015, za: http://carnegieendowment.org/2015/10/05/ukraine-reform-monitoroctober-2015-pub-61510 (08.07.2016).

144 The website on self-governance processes in Ukraine, za: https://storage.decentralization.gov.ua/uploads/library/file/309/10.09.2018.pdf, (10.09.2018).
} 


\section{Streszczenie:}

Reforma samorządności i decentralizacja były jednym z priorytetowych zagadnień w programie politycznym władz postmajdańskich na Ukrainie. Co więcej, był szeroko stosowany $\mathrm{w}$ debacie politycznej na temat prezydenckiej ustawy o decentralizacji, co doprowadziło do politycznych sporów w ukraińskim parlamencie. Dlatego artykuł kładzie nacisk na retoryczne strategie kluczowych aktorów politycznych w odniesieniu do ich stanowiska wobec procesu głosowania nad projektem ustawy o decentralizacji. Pod względem metodologicznym takie metody, jak analiza systemów, analiza instytucjonalna i prawna, krytyczna analiza dyskursu oraz porównanie, okazały się szczególnie istotne w badaniach artykułów i umożliwiły wyjaśnienie głównych cech projektu decentralizacji, okoliczności politycznych i wyników dyskurs polityczny stosowany przez polityków podczas głosowania.

\section{Słowa klucz:}

Decentralizacja, polityka, władza, retoryka prezydencka

\section{Key words:}

decentralization, political discourse, self-governance, presidential rhetoric

\section{Bibliografia:}

1. Aristotle, Politics, trans. Ernest Barker. New York, 1970.

2. Aristotle, Rhetoric, trans. Rhys Roberts. New York, 1954.

3. Chilton P., Analysing Political Discourse: Theory and Practice, London, 2004.

4. Denton R., Introduction to Craig Allen Smith, Kathy B. Smith, The White House Speaks: Presidential Leadership as Persuasion. New York, 1994.

5. Dobek - Ostrowska B., Komunikowanie polityczne i publiczne, Warszawa, 2011.

6. Fairclough N., Duszak A., Wstęp: Krytyczna analiza dyskursu-nowy obszar badawczy dla lingwistyki i nauk społecznych. „Krytyczna analiza dyskursu. Interdyscyplinarne podejście do komunikacji społecznej”Kraków, 2008.

7. Kompleks mer po vypolneniuju Minskih soglashenii, za: http://www.osce.org/ru/cio/140221?download=true.

8. Olszański T., Ukraine is divided over constitutional reform, za: http://www.osw.waw.pl/en/publikacje/analyses/2015-09-02/ukraine-divided-overconstitutional-reform.

9. Peremoga chy zrada-shcho oznachayut novi polozhennya Konstytuciji pro status Donbasu, za: http://ual.com.ua/publications/peremoga-chi-zrada-shcho-oznachayutnovi-polozhennya-konstituciji-pro-status-donbasu-5917.html.

10. Perloff Richard M., Political Communication: Politics, Press and Public in America. New York, 1998.

11. Podrobyci za lashtunkamy konstytuciynoyi komisii, za: http://day.kyiv.ua/uk/article/podrobyci/za-lashtunkamy-konstytuciynoyi-komisiyi.

12. Poroshenko: ti, hto ne golosuvav za decentralizaciju, namagalysia "torpeduvaty myrnyy plan”, za: http://www.newsru.ua/ukraine/17jul2015/torpedirovatplan.html.

13. Project zmin do Konstytucji zberigaje balans, za: http://www.theinsider.ua/politics/559bb0616c6fe/.

14. Smith C., Smith K., The White House Speaks: Presidential leadership as Persuasion. 
New York, 1994.

15. The Bill number 2217 "On Amendments to the Constitution of Ukraine (concerning the decentralization of power),

za: http://w1.c1.rada.gov.ua/pls/zweb2/webproc4_1?pf3511=55812.

16. The Law of Ukraine on Special Order of Local Self-Government in parts of Donetsk and Lugansk regions, za: http://zakon5.rada.gov.ua/laws/show/1680-18.

17. Woldsfeld G., Maarek P., Political Communication in a New Era: a Cross - National Perspective. New York, 2003.

18. za: https://www.president.gov.ua/en/news/decentralizaciya-nablizit-nashu-politichnusistemu-do-yevrop-35658.

19. za: https://www.president.gov.ua/news/vistup-prezidenta-ukrayini-na-plenarnomuzasidanni-verhovnoy-35657.

20. Zminy Konstytucii: decentralizacija pid vyhuky „Hanba”, za: http://www.radiosvoboda.org/a/27218913.html 